\title{
Genetic Variability and Correlation Studies in Garlic (Allium sativum L.)
}

\author{
S. V. Sable ${ }^{1}$, D. T. Deshmukh ${ }^{2 *}$, S. M. Ghawade ${ }^{3}$ and S. S. Rawat ${ }^{1}$ \\ ${ }^{1}$ Department of Agricultural Botany, ${ }^{2}$ Directorate of Research (Seed), \\ ${ }^{3}$ Chilli and Vegetable Research Unit, Dr. Panjabrao Deshmukh Krishi Vidyapeeth, \\ Akola - 444104, Maharashtra, India \\ *Corresponding author
}

A B S T R A C T

\begin{tabular}{l} 
Key w o r d s \\
$\begin{array}{l}\text { Genotypes of garlic } \\
\text { environment } \\
\text { neck thickness }\end{array}$ \\
\hline Article Info \\
$\begin{array}{l}\text { Accepted: } \\
\text { 05 April } 2020 \\
\text { Available Online: } \\
\text { 10 May } 2020\end{array}$ \\
\hline
\end{tabular}

Eleven genotypes of garlic were evaluated for genetic variability and correlation for fifteen quantitative traits. The magnitude of phenotypic coefficient of variation was found greater than the corresponding genotypic coefficient of variation for all the characters indicating the importance of environment in expression of characters. High estimates of heritability (broad sense) coupled with high genetic advance as percentage of mean were observed for number of cloves per bulb, leaf length $(\mathrm{cm})$, neck thickness $(\mathrm{cm})$ and average weight of dry bulb ( $\mathrm{g}$ ) indicating preponderance of additive genetic variance, which could be exploited through selection for the improvement of these characters. The positive and significant genotypic correlation of plant height, neck thickness, polar diameter of clove, equatorial diameter of clove, number of cloves per bulb, average weight of 10 clove, average weight of fresh bulb with yield per plot and their significant correlation among them revealed its importance while selection during breeding programme.

\section{Introduction}

Garlic (Allium sativum L.; $2 \mathrm{n}=16$ ), is an important spice crop belongs to the family Alliaceae. Garlic contains average 59-78\% water, $6 \%$ protein, $0.5 \%$ liphid, $33 \%$ carbohydrates, $2 \%$ fibre, $1 \%$ sugar and volatile oil known as diallyl disulphide which is the major flouring component in garlic. The area and production of India under garlic crop during 2015-16 was reported to be 262.04 thousand hectares and production 1425.46 thousand tonnes with productivity of $5.4 \mathrm{t} / \mathrm{ha}$. (Anon, 2016) Madhya Pradesh is a leading state accounting for 21.17 thousand hectares with 424.50 thousand tonnes of production followed by Gujarat, Uttar Pradesh and Rajasthan (Anon, 2015).

In Maharashtra, it is grown on 3500 ha area with the production 40000 tonnes. The presence of local types with the farmers and it's adaption on their field imposes the scope for varietal breeding with wider adaptability 
and high yield. Therefore, in present studies selection made from local types were evaluated for their variability and to estimates inherent association between genes controlling two characters. The inferences of the studies could help the breeder for genetic improvement in garlic.

\section{Materials and Methods}

The experimental material comprised of eleven genotypes of Garlic, Which includes eight lines selected from local viz., AKG-1, AKG -2, AKG -3, AKG-4, AKG-5 , AKG-6, AKG-7 , AKG -8 and three checks Viz., G-4, Godawari and G-282. These genotypes were evaluated in Randomized Block Design at Chilli and Vegetable Research Unit, Dr. PDKV, Akola (Maharashtra) during Rabi season 2016-2017. Each genotype was grown in one plot of $3.20 \times 1.50 \mathrm{~m}^{2}$ length in each replication with the spacing of $10 \times 10 \mathrm{~cm}$.

The observation were recorded on five randomly selected plants of each genotype in each replication for fifteen characters viz., Plant height at maturity $(\mathrm{cm})$, Number of leaves per plant, Neck thickness ( $\mathrm{cm})$, Leaf length $(\mathrm{cm})$, Leaf width $(\mathrm{cm})$, Polar diameter of bulb $(\mathrm{cm})$, Equatorial diameter of bulb (cm), Polar diameter of clove (cm), Equatorial diameter of clove $(\mathrm{cm})$, Number of cloves per bulb, Average weight of 10 clove $(\mathrm{g})$, Average weight of fresh bulb(g), Average weight of dry bulb(g), TSS (\%) and yield per plot $(\mathrm{kg})$. Analysis of variance was done as per the methodology suggested by Panse \& Sukhatme (1988). The genetic parameters viz., genotypic and phenotypic coefficient of variation, heritability (broad sense) and genetic advance were estimated using the formulae suggested by Burton (1952) and Lush (1949). The genotypic correlation coefficients were calculated as per method suggested by Johnson et al., 1955.

\section{Results and Discussion}

Any breeding programme of genetic improvement requires basic information regarding the genetic variability present in the crop. Correlation studies help the breeder for selection of the other characters which has a significant association with yield .The analysis of variance revealed significant difference among the genotypes for all traits studied. The phenotypic coefficient of variation (PCV), genotypic coefficient of variation $(\mathrm{GCV})$, heritability $\left(\mathrm{h}^{2}\right)$ in broad sense, genetic advance (GA) and genetic gain as per cent of mean for various characters are presented in Table 1. The results indicated that phenotypic variance were higher than the genotypic variance indicating the influence of environment.

The phenotypic variation based on mean values is not the precise criterion to estimate extent of variability therefore better index for measuring the genetic variability is genotypic coefficient of variation (GCV) as described by Burton (1952). The highest GCV was recorded in Number of cloves per bulb (29.42 $\%)$ followed by neck thickness (14.68\%), Average weight of dry bulb (13.94 \%), Average weight of 10 cloves $(12.66 \%)$ and leaf length (12.63\%). The estimates of heritability in broad sense were very high to high for Number of cloves per bulb $(91.87 \%)$, Leaf width $(87.18 \%)$,

Average weight of dry bulb (70.56\%). Whereas, it was moderate for yield per plot $(68.49 \%)$, Nick thickness $(68.19 \%)$ and leaf length $(62.08 \%)$. The results were close proximate to that of Singh et al., (2012). Heritability values together with genetic advance would be more useful in predicting the response to selection (Johnson et al., 1955). High heritability estimates coupled with moderate to high genetic advance as percent of mean (GAM) was recorded for 
number of cloves per bulb $\left(\mathrm{H}^{2}=91.87 \%\right.$, GAM $=58.09 \%$ ), average weight of dry bulb $\left(\mathrm{H}^{2}=70.56 \%, \mathrm{GAM}=24.13\right)$, neck thickness $\left(\mathrm{H}^{2}=68.19 \%, \mathrm{GAM}=24.97 \%\right)$ and leaf length length $\left(\mathrm{H}^{2}=62.08 \%, \mathrm{GAM}=20.50 \%\right)$. The results were closing proximate to that of Vatsyayan (2013). Thus, the characters number of cloves per bulb, average weight of dry bulb, nick thickness and leaf length which has exhibited high GCV \%, high to moderate heritability estimates coupled with high to moderate genetic gain suggesting the preponderance of additive genes and could be exploited under selection in breeding programme.

Table.1 Estimates of genetic parameters for the fifteen characters in garlic

\begin{tabular}{|c|c|c|c|c|c|c|}
\hline $\begin{array}{l}\text { S. } \\
\text { No. }\end{array}$ & Characters & $\begin{array}{c}\text { GCV } \\
\%\end{array}$ & $\begin{array}{c}\text { PCV } \\
\%\end{array}$ & $\begin{array}{l}\mathbf{h}^{2} \\
\%\end{array}$ & GA & $\begin{array}{c}\text { GAM } \\
\%\end{array}$ \\
\hline 1. & Plant height $(\mathrm{cm})$ & 6.38 & 11.05 & 33.29 & 4.43 & 7.58 \\
\hline 2. & Number of leaves per [plant & 4.29 & 7.66 & 31.35 & 0.45 & 4.94 \\
\hline 3. & Neck thickness $(\mathrm{cm})$ & 14.68 & 17.77 & 68.19 & 0.22 & 24.97 \\
\hline 4. & Leaf length $(\mathrm{cm})$ & 12.63 & 16.03 & 62.08 & 7.94 & 20.50 \\
\hline 5. & Leaf width $(\mathrm{cm})$ & 6.80 & 7.28 & 87.18 & 0.19 & 13.08 \\
\hline 6. & Polar diameter of bulb $(\mathrm{cm})$ & 4.36 & 7.57 & 33.12 & 0.14 & 5.16 \\
\hline 7. & $\begin{array}{l}\text { Equatorial diameter of bulb } \\
(\mathrm{cm})\end{array}$ & 3.80 & 5.85 & 42.18 & 0.18 & 5.08 \\
\hline 8. & Polar diameter of clove $(\mathrm{cm})$ & 6.33 & 9.28 & 46.6 & 0.15 & 8.90 \\
\hline 9. & $\begin{array}{l}\text { Equatorial diameter of clove } \\
(\mathrm{cm})\end{array}$ & 5.76 & 9.79 & 34.65 & 0.06 & 6.99 \\
\hline 10. & Number of clove per bulb & 29.42 & 30.69 & 91.87 & 14.74 & 58.09 \\
\hline 11. & $\begin{array}{l}\text { Average weight of ten clove } \\
\text { (g) }\end{array}$ & 12.66 & 19.42 & 42.53 & 3.58 & 17.01 \\
\hline 12. & $\begin{array}{l}\text { Average weight of fresh bulb } \\
\text { (g) }\end{array}$ & 7.63 & 12.51 & 37.25 & 2.14 & 9.59 \\
\hline 13. & $\begin{array}{l}\text { Avrage weight of dry bulb } \\
\text { (g) }\end{array}$ & 13.94 & 16.60 & 70.56 & 4.66 & 24.13 \\
\hline 14 & T.S.S. ( \%) & 5.54 & 9,02 & 37.66 & 2.76 & 7.00 \\
\hline 15 & Yield per [plot( Kg ) & 7.42 & 8.96 & 68.49 & 0.22 & 12.64 \\
\hline
\end{tabular}


Table.2 Genotypic correlation coefficients among the fifteen characters

\begin{tabular}{|c|c|c|c|c|c|c|c|c|c|c|c|c|c|c|c|}
\hline Characters & PH & NL & NT & $\mathbf{L L}$ & $\mathbf{L W}$ & PDB & ED B & PD C & ED C & NC B & AW $10 \mathrm{C}$ & AW FB & AW DB & TSS & YP \\
\hline PH & 1.00 & -0.172 & $0.998^{* *}$ & $-0.903 * *$ & -0.031 & 0.454 & 0.122 & $0.727 * *$ & $0.627^{*}$ & 0.114 & $0.854 * *$ & -1.014 & -0.330 & 0.179 & $0.918 * *$ \\
\hline NL & & 1.00 & 0.463 & -0.005 & $0.648 * *$ & $-0.484 *$ & -0.766 & 0.306 & -0.192 & -0.106 & -0.048 & 0.196 & -0.132 & -0.171 & 0.069 \\
\hline NT & & & 1.00 & 0.543 & -0.299 & 0.531 & -0.005 & $0.528 *$ & $0.991 * *$ & 0.073 & $0.824 *$ & $-0.586^{*}$ & -0.230 & 0.223 & $0.451 *$ \\
\hline $\mathbf{L L}$ & & & & 1.00 & -0.194 & 0.359 & 0.597 & $0.534^{*}$ & $0.636 * *$ & $0.464 *$ & 0.295 & 0.051 & 0.237 & 0.124 & 0.229 \\
\hline LW & & & & & 1.00 & $-0.693 * *$ & -0.435 & 0.405 & -0.174 & -0.418 & -0.152 & -0.282 & $-0.721 * *$ & -0.707 & 0.087 \\
\hline PD B & & & & & & 1.00 & 0.030 & 0.096 & $0.749 * *$ & 0.060 & $0.584 *$ & $-0.819 * *$ & 0.088 & 0.925 & 0.321 \\
\hline ED B & & & & & & & 1.00 & -0.489 & $0.597 *$ & 0.619 & -0.297 & 0.239 & $0.382 *$ & 0.137 & $-0.603 * *$ \\
\hline PD C & & & & & & & & 1.00 & 0.707 & $-0.617 *$ & 0.389 & -0.722 & -0.523 & 0.099 & $0.532 *$ \\
\hline ED C & & & & & & & & & 1.00 & 0.053 & $0.393 *$ & $-0.730 *$ & -0.207 & $0.620 *$ & $0.989 * *$ \\
\hline NC B & & & & & & & & & & 1.00 & -0.038 & $0.754 * *$ & $0.787 * *$ & -0.268 & $0.545^{*}$ \\
\hline AW 10 B & & & & & & & & & & & 1.00 & $-0.935 * *$ & -0.244 & 0.471 & $0.598^{*}$ \\
\hline AW F B & & & & & & & & & & & & 1.00 & $-0.926 * *$ & 0.349 & $0.970 * *$ \\
\hline AW D B & & & & & & & & & & & & & 1.00 & $0.805 * *$ & -0.484 \\
\hline TSS & & & & & & & & & & & & & & 1.00 & 0.193 \\
\hline
\end{tabular}

$*=5 \%$ level of significance,$* *=1 \%$ level of significance

Abbreviations used for characters:-

$\mathrm{PH} \quad$ : Plant height $(\mathrm{cm})$

ED C : Equatorial diameter of clove $(\mathrm{cm})$

NL : Number of leaves perplant

NC B : Number of clove per bulb

NT : Neck thickness (cm)

AW $10 \mathrm{C}$ : Average weight of 10 clove $(\mathrm{g})$

LL : Leaf length

AW F B : Average weight of fresh bulb ( g)

LW : Leaf width $(\mathrm{cm})$

AW D B: Average weight of dry bulb ( $\mathrm{g}$ )

PD B : Polar diameter of bulb $(\mathrm{cm})$

TSS : Total soluble solid ( \%)

D B : Equatorial diameter of bulb $(\mathrm{cm})$

YP :Yield per plot ( $\mathrm{kg}$ ) .

PD C : Polar diameter of clove $(\mathrm{cm})$ 
The correlation coefficient indicates the nature of association among the different traits. The characters that are positively correlated with yield are of considerably important for plant breeder for selection purpose. In present investigation ( Table 2 ) yield per plot has shown significant positive correlation with plant height (0.918), neck thickness (0.451), polar diameter of clove (0.532), equatorial diameter of clove (0.989), number of cloves per bulb (0.545), average weight of 10 clove $(0 . .598)$, average weight of fresh bulb (0.970).

Moreover, these character also exhibited positive and significant correlation among themselves Viz plant height with neck thickness $(\mathrm{r}=0.998)$, equatorial diameter of clove $(r=0.627)$ and average weight of 10 clove $(r=0.857)$. Neck thickness with equatorial diameter of clove $(\mathrm{r}=0.991)$ and average weight of 10 clove $(r=0.824)$. Equatorial diameter of bulb with average weight of 10 clove $(r=0.393)$. This resembles to the finding of Srivastava et al., (1993), Kohali anmd Mahajan (1993) Dhall and Brar (2013), Rahman and Das (1985) and Sonkiya et al., (2012).

Thus, the selection based on the characters viz., plant height, neck thickness, polar diameter of clove, equatorial diameter of clove, number of cloves per bulb, average weight of 10 clove, average weight of fresh bulb could help in genetic improvement programme in garlic.

\section{References}

Anonymous 2015. www.nhrdf.org.

Anonymous 2016. Spices Statistics at Glance 2016. By Directorate of Arecanut and spices Development, GOI, Calicut (Kerala).
Burton, G.W. 1952. Quantitative inheritance in grasses. Proc. Int. Grassland Congr. 6:277-283.

Dhall, R.K. and Brar ,P.S. 2013. Genetic variability, correlation and path coefficient studies in garlic (Allium sativum L.) Vegetable science , 2 (2): 102-104.

Johnson, H.W., Robinson, H.F. and Comstock, R.E. 1955. Estimates of genetic and environmental variability in soybean. Agronomy Journal, 47:314318.

Kohali, U.K. and Mahajan, Nutun .1993. Yield performance and correlation studies in Garlic. A note, Haryana Journal of Horticulture Sciences . 22: 163-165.

Lush, J.L. 1949. Intra-sire correlation or regression offspring on dam as a method of estimating heritability of characteristics. Ann. Prod. Am. Animal Prod., 33:293-301.

Panse, V.G. and Sukhatme, P.V. 1988. Statistical methods for agricultural worker, ICAR Publ., (II ed.), New Delhi.

Rahman, A.K.M.M. and Das, M.K.1985. Correlation and path analysis in garlic. Bangladesh Journal of Agricultural Research .10: 50-54.

Srivastava, B.P.,Dubey ,A.K. and Srivastava J.P. 1993. Genetic association and path analysis in Garlic . Haryana Journal of Horticultural Sciences. 22(1) 85-88.

Sonkiya ,A.K.,Singh ,P.P. and Naruka, I.S. 2012. Variability, character association and path coefficient analysis in garlic . Medicinal Plant .4(2) : 90-93.

Vatsyayan,S, Brar,P.S. and Dhall,PR.K. 2013. Genetic variability studies in garlic (Allum sativum L.). Annals of Horticulture .6(2) : 315-320. 


\section{How to cite this article:}

Sable. S. V., D. T. Deshmukh, S. M. Ghawade and Rawat. S. S. 2020. Genetic Variability and Correlation Studies in Garlic (Allium sativum L.). Int.J.Curr.Microbiol.App.Sci. 9(05): 358363. doi: https://doi.org/10.20546/ijcmas.2020.905.040 